
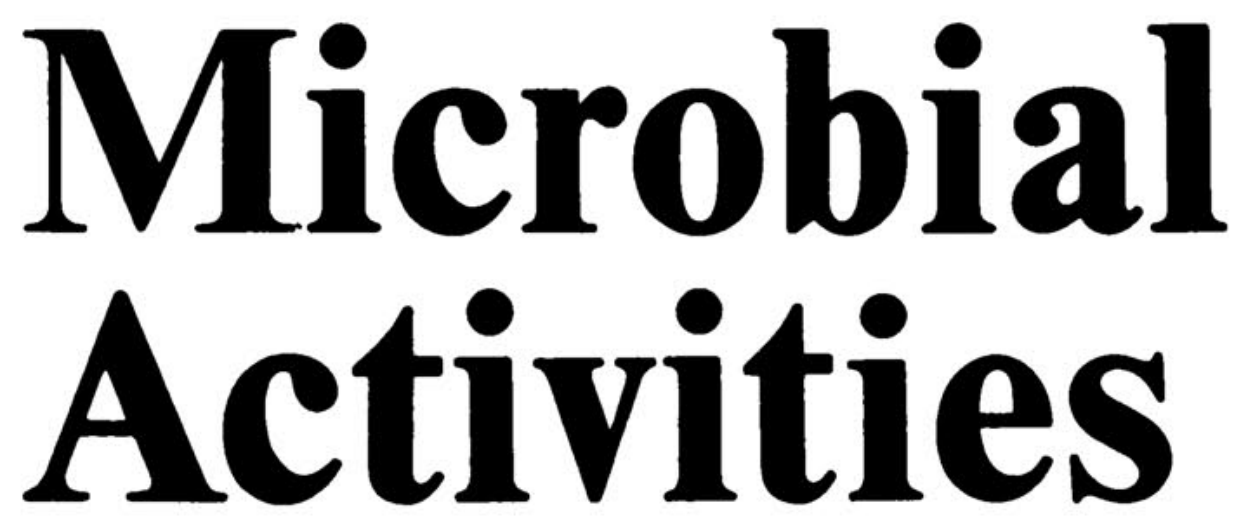

J. H. T. Luong, B. Volesky

Heat Evolution During the Microbial Process - Estimation, Measurement, and Applications

F. Parisi

Energy Balances for Ethanol as a Fuel

B. Sonnleitner

Biotechnology of Thermophilic Bacteria - Growth, Products, and Application

E. N. Kondratieva, I. N. Gogotov

Production of Molecular Hydrogen in Microorganisms 

Microbial Activities 



\section{Microbial Activities}

Managing Editor: A. Fiechter

with 46 Figures and 46 Tables

Akademie-Verlag $\cdot$ Berlin 1984

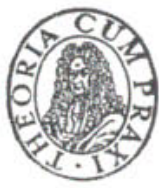


Die Originalausgabe erscheint im Springer-Verlag

Berlin-Heidelberg-New York-Tokyo

als Volume 28 der Schriftenreihe Advances in Biochemical

Engineering/Biotechnology

Vertrieb ausschließlich für die DDR und die sozialistischen Länder

Alle Rechte vorbehalten

(C) Springer-Verlag Berlin-Heidelberg 1983

Erschienen im Akademie-Verlag Berlin, DDR-1086 Berlin, Leipziger Straße 3-4

Lizenznummer: $202 \cdot 100 / 508 / 84$

Printed in the German Democratic Republic

Gesamtherstellung: VEB Druckerei „Thomas Müntzer“, 5820 Bad Langensalza

Umschlaggestaltung: Karl Salzbrunn

LSV 1345

Bestellnummer: 7633489 (6822)

08600 